\title{
ARAŞTIRMA/RESEARCH
}

\section{Çocuklarda akut piyelonefrit ve böbrek parankim zedelenmesinde MAG3 sintigrafinin ve DMSA sintigrafinin tanısal değeri}

\author{
Diagnostic value of MAG3 scintigraphy and DMSA scintigraphy in renal \\ parenchyma damage and acute pyelonephritis of children
}

Buket Kilıçaslan ${ }^{1}$, Handan Alp², Mustafa Yıldırım³ ${ }^{3}$, Tacettin İnand1 ${ }^{4}$

${ }^{1}$ Özel Adana Metro Hastanesi, Çocuk Sağlığı ve Hastalıkları, Adana, Turkey

${ }^{2}$ Atatürk Üniversitesi Tıp Fakültesi, Çocuk Sağlığı ve Hastalıkları, Erzurum, Turkey

${ }^{3}$ Ankara Turgut Özal Üniversitesi, Nükleer Tip Anabilim Dalı, Ankara, Turkey

${ }^{4}$ Mustafa Kemal Üniversitesi, Halk Sağlığı Anabilim Dalı, Hatay, Turkey

Cukurova Medical Journal 2016;41(3):464-471.

\section{Abstract}

Purpose: In this study, we aimed to compare diagnostic value of MAG3 scintigraphy in renal parenchyma damage and acute pyelonephritis, in the first urinary tract infection in children, with DMSA scintigraphy.

Material and Methods: Seventy patients who never diagnosed before but admitted with complaints of urinary tract infection for the first time, were included in this study. Before the treatment of all patients in the study were taken blood and urine samples, and leukocyte count, erythrocyte sedimentation rate, C-reactive protein concentration were determined. DMSA scintigraphy in detection of renal parenchyma damage was accepted as "gold standard". In the detection of damage in renal parenchyma, positive and negative predictive value, selectivity and sensitivity of MAG3 scintigraphy were detected.

Results: The fever, elevated leukocytes, C-reactive protein and sedimentation rate were found statistically significant in the detection of pyelonephritis. However, these values were not significant statistically in the demonstration of the severity of parenchyma damage. In the detection of damage in renal parenchyma, MAG3 scintigraphy had a sensitivity of $32.5 \%$ and a specificity of $98.1 \%$.

Conclusion: MAG3 scintigraphy can not replace DMSA scan to determine the renal parenchyma damage in childhood.

Key words: Pyelonephritis, MAG3, DMSA, scintigraphy.
Öz

Amaç: Çalışmamızda, bulgu veren ilk idrar yolu enfeksiyonu olan çocuklarda akut piyelonefrit ve böbrek parankim zedelenmesinde MAG3 sintigrafinin tanisal değeri ve DMSA sintigrafi ile karşılaştırılması amaçlanmıștır.

Gereç ve Yöntem: İdrar yolu enfeksiyonu düşündüren şikayetlerle başvuran, daha önce idrar yolu enfeksiyonu tanısı almamış, 70 hasta çalıșma kapsamına alındı. Çalışmaya alınan tüm hastaların tedavisi yapılmadan önce, kan ve idrar örnekleri alınarak, lökosit sayısı, sedimentasyon hız1, C-reaktif protein konsantrasyonu saptandi. Böbrek parankim zedelenmesinin saptanmasında DMSA sintigrafi 'altın standart' tanı yöntemi kabul edildi. Bulgu veren ilk idrar yolu enfeksiyonu tanisı alan çocuklarda, böbrekte parankim zedelenmesini saptamada MAG3 sintigrafinin duyarlılık, seçicilik, pozitif ve negatif kestirim değeri saptand.

Bulgular: Çalışmamızın sonucunda, piyelonefrit ve sistitli olgularımızın ayrımında ateş, lökosit, C-reaktif protein ve sedimentasyon yüksekliği istatistiksel olarak oldukça anlamlı bulundu; ancak, bu değerlerin, DMSA sintigrafide saptanan parankim zedelenmesinin şiddetini göstermede istatistiksel olarak anlamlılık taşımadı̆̆ı saptandı. Böbrek parankim zedelenmesini göstermede, MAG3 sintigrafinin duyarlılığ1 \% 32,5, seçiciliği ise $\% 98,1$ saptandı.

Sonuç: Çocuklarda, MAG3 sintigrafinin böbrek parankim zedelenmesini belirlemede DMSA sintigrafinin yerini alamayacağı kanısına varıldı.

Anahtar kelimeler: Piyelonefrit, MAG3, DMSA, sintigrafi

Yazışma Adresi/Address for Correspondence: Dr. Buket Kılıçaslan, Özel Adana Metro Hastanesi, Çocuk Sağlı̆̆1 ve Hastalıklar1, Adana, Turkey E-mail: drbuketk73@yahoo.com

Geliș tarihi/Received: 04.01.2016 Kabul tarihi/Accepted: 21.02.2016 


\section{GİRİ̧}

İdrar yolu enfeksiyonu (IYE) çocuklarda solunum yolu enfeksiyonlarından sonra en sik görülen enfeksiyondur ${ }^{1,2}$. Erken tan1, uygun ve yeterli tedavi yapılmadığında kronik piyelonefrit, hipertansiyon ve böbrek yetmezliği gibi ciddi sonuçlara yol açabilmeleri nedeniyle çocukluk çağında üzerinde önemle durulmas1 gereken bir hastalıktı1 ${ }^{1-3}$. Dolayısıla hekim, IYE'nu tanımak, gerekli incelemeleri yapmak, erken ve yeterli tedavi uygulamakla yükümlüdür.

IYE, böbrek parankimini tutarak akut piyelonefrit, mesaneyi tutarak akut sistit şeklinde seyredebilir. Ateşli, küçük çocuklarda bu ayrımın yapılması güçtür. Enfeksiyon piyelonefrit gibi kabul edilerek gerekli inceleme, tedavi ve izlem uygulanmalıdır. Bu şekilde böbrekte skar gelişme riski azaltılabilir2,4. Günümüzde, DMSA sintigrafi, çocuklarda böbrek parankim zedelenmesini göstermede 'altın standart' tanı yöntemi olarak kabul edilmektedir ${ }^{2,5}$. Merkaptoasetiltriglisin (MAG3) ile sintigrafi ise böbreğin hem parankimini hem de işlevini göstermede yararlıdır. MAG3 sintigrafi ile akut veya kronik böbrek zedelenmesi belirlenebilir. Aynı zamanda kortikal skar ile piyelonefritin genişlemiş pelvikaliksiyel sistemden kaynaklanan azalmış kortikal radyoizotop madde tutulumunun ayrıminda yardımcı olabilir ${ }^{6}$. Ancak, bulgu veren ilk kez IYE geçirmekte olan çocuklarda, akut piyelonefriti ve böbrek parankim zedelenmesini göstermede MAG3 ile yapılan yeterli sayıda sintigrafik çalışma yoktur.

Bu çalışmada, çocukluk çağında bulgu veren ilk IYE olan çocuklarda akut piyelonefrit ve böbrek parankim zedelenmesinde MAG3 sintigrafinin ve DMSA sintigrafinin tanısal değerinin saptanması amaçlanmıştır.

\section{GEREÇ VE YÖNTEM}

Çalışma, Atatürk Üniversitesi Yakutiye Araştırma Hastanesi Çocuk Sağllı̆ı ve Hastalıkları Polikliniği'nde prospektif olarak, altı ayı kapsayan süre içinde yapıldı. Çalışma için Atatürk Üniversitesi Tıp Fakültesi Araştırma Etik Komitesi'nin onayı alındı. IYE düşündüren şikayetlerle başvuran, daha önce IYE tanısı almamış ve idrar kültüründe 105 veya daha fazla koloni mikroorganizma üreyen hastalardan, ultrasonografi (USG) ile böbrekte yapısal anomali saptanmayan 70 hasta çalışma kapsamına alındı. Sistemik inceleme yapıldı. Beş parametreli otomatik kan hücre sayıcı ile tam kan sayımı yapılarak lökosit değerleri saptandı. Birinci saatteki 20 mm'nin üzerindeki sedimentasyon hız1 yüksek olarak değerlendirildi. Serum CRP konsantrasyonu $0,5 \mathrm{mg} / \mathrm{L}$ 'nin üzeri pozitif kabul edildi. Koltuk altından ölçülen beden $151 s 138^{\circ} \mathrm{C}$ ve üzerinde olduğunda ateşin varlığı kabul edildi. İdrar örnekleri, tuvalet alışkanlığı olan çocuklarda orta akım idrarı şeklinde, tuvalet alışkanlı̆̆1 olmayan çocuklarda ise steril idrar torbasıyla alındı. Kültür için alınan örnekler en fazla 20-30 dakika içinde besiyerine ekildi. Orta akım idrar örneğinde bir kez 100000 koloni veya üzerinde mikroorganizma üreyen hastalar ile idrar torbası kullanılarak üç kez idrar kültürü alınan hastalardan en az ikisinde 100 000 koloni veya üzerinde mikroorganizma üreyen hastalara IYE tanısı konuldu.

Hastalarımıza kliniğe getirildikten sonraki ilk 5-7 gün içerisinde birer gün arayla DMSA sintigrafi ve MAG3 sintigrafi yapıldı. DMSA sintigrafik çalışma için hastalara verilecek olan radyofarmasötik ajan, en düşük doz $10 \mathrm{MBq}(0,3 \mathrm{mCi})$, en yüksek doz ise 110 $\mathrm{MBq}(3 \mathrm{mCi})$ olacak şekilde beden yüzeyalanı ölçülerek hesaplandı. Hastalara DMSA sintigrafi çekilirken, "GE medical systems infinia Israel" ve "SIEMENS symbia true SPECT CT USA" cihazlar1 ile planar görüntüler elde edildi. Hastalara intravenöz yolla ${ }^{99 \mathrm{~m}} \mathrm{Tc}-\mathrm{DMSA}$ verilmesinden 4 saat sonra ön, arka, sağ arka oblik, sol arka oblik pozisyonlarında görüntüler alındı. Piyelonefrit tanısı, fokal ve diffüz olarak DMSA tutulum yokluğu veya azlığ1 ile konuldu. ${ }^{99 m}$ Tc-MAG3 dinamik böbrek sintigrafisinde, çekimlere başlamadan önce gama kameranın enerjisi $140 \mathrm{KeV}$ ve $\% 20$ 'lik enerji penceresine ayarlandi. Radyoaktif madde $0,20 \mathrm{mCi} / \mathrm{kg}$ standart dozunda verildi.

Görüntüleme için genel amaçlı, geniş görüş açıll, düşük enerjili, paralel delikli kolimatör takılı gama kameralar kullanıldı. Görüntüler iki ayrı gama kamerada (General Elektrik 3200 XRrr ve General Elektrik 4000 Crr) alındı. Görüntüleme arka projeksiyondan hastanın sirt üstü yatar durumda olması sağlanarak yapıldı. Bazı hastalarda ise önden de görüntüler alındı.

99m'Tc-MAG3 dinamik böbrek sintigrafisinde faz 1, iki saniyelik 24 frame (toplam $48 \mathrm{sn}$ ); faz 2, onbeş saniyelik 16 frame ( $240 \mathrm{sn}$ ) ve faz 3 ise otuz saniyelik 40 frame (1200 sn) olmak üzere toplam 1488 saniyelik (yaklaşık 25 dakikalık) görüntüler alındı. Hastaların idrar yapma sonrası görüntüleri elde edilerek bilgisayara kaydedildi. 


\section{BULGULAR}

Çalışma kapsamında yer alan 70 hastanın 45'i (\% 64.3) piyelonefrit, $25 \%(\%$ 35.7) sistit tanısını aldı. Hastalarımızın 48’i (\% 68.6) 5 yaşın üzerindeyken, 22 'si (\% 31.4) 5 yaş ve altında idi. Yaş gruplarına göre piyelonefrit ve sistit sıklığ1 ile istatistiksel olarak anlamlllıkları Tablo-1'de gösterildi. Yaş azaldıkça, bulgu veren ilk IYE varlığında piyelonefrit görülme oranının arttığ 1 ve bu durumun istatistiksel olarak anlamlılık taşıdığı gözlendi ( $\mathrm{p} \leq 0.05)$. Hastaların 46's1 (\% 65.7) kız, 24'ü (\% 34.3) erkekti. Kızların (n=46) $30 ' \mathrm{u}(\%$ 65.2) piyelonefrit tanis1 alırken, 16's1 (\% $34.8)$ sistit tanisi aldi. Erkeklerin ise $(n=24) 15$ 'inde (\% 62.5) piyelonefrit saptanırken, 9'unda (\% 37.5) sistit saptandi. Piyelonefritli ve sistitli olguların cinsiyete göre dağılımı istatistiksel olarak anlamlı bulunmad1 ( $>0.05)$. Piyelonefrit tanısı alan hastalarımızın en sık kliniğe getirilme şikayeti ateş (\% 91.1) iken, sistit tanıs1 alan hastalarımızın en s1k kliniğe getirilmesi s1k idrar yapma (\% 68) şikayeti ile oldu (Tablo-2). Piyelonefrit ve sistit tanilı hastalarımızda en sik üreyen mikroorganizma (sırasiyla \% 77.8 ve \% 72) E.coli iken, ikinci sırada (sırasiyla \% 13.3 ve \% 16) P.mirabilis yer aldı (Tablo3). Hastalarımizin beden isisi ve laboratuvar bulgularının ortalama değerleri ve standart sapmaları karşılaştırıldığında (Tablo-4), piyelonefritli hastalarımızda beden 1sıs1, lökosit, CRP ve sedimentasyon değerleri sistitli hastalarımızdan belirgin olarak yüksek bulundu ve bu durum istatistiksel olarak anlamliydi ( $\mathrm{p}=0.001)$. Hastalarımızda değişken verilerin (koltuk altından ölçülen beden 1sısı ile laboratuvarda bakılan lökosit sayıs1, CRP ve sedimentasyon değerleri) akut piyelonefriti göstermedeki duyarlılık ve seçiciliği ile yine bu verilerin kesme noktas1, "ROC Area" ve p değerleri irdelenerek Tablo-5'te gösterildi.

Çalışma kapsamına aldığımız hastalarda, akut piyelonefriti saptamada MAG3 sintigrafinin DMSA sintigrafiye göre duyarlılık ve seçiciliği incelendiğinde, duyarlılı̆̆ının \% 32.5, seçiciliğinin \% 98.1 olduğu görüldü. MAG3 sintigrafinin pozitif kestirim değeri yüksek olup \% 96.5 iken, negatif kestirim değeri ise \% 47.7 ile oldukça düşük bulundu.

Çalışma kapsamına alınan olgularda, şikayetin başlaması ile tedavinin başlaması arasında geçen sürenin, DMSA sintigrafide saptanan böbrek parankim zedelenmesi üzerine etkisi irdelendiğinde, bu sürenin '48 saat ve altında' saptandığ1 26 olgunun 8 'inde (\% 30.8) parankim zedelenmesi varken, '48 saatten fazla' sürenin geçtiği saptanan 44 olgunun 37 sinde (\% 84.1) parankim zedelenmesi gözlendi. Olgularımızda tedavi başlama süresinin uzaması durumunda böbrekte parankim zedelenmesinin oluşma olasılığının arttı̆̆ı saptanırken, bu durum istatistiksel olarak oldukça anlamlı $(\mathrm{p}=0.001)$ bulundu (Tablo-6).

Tablo 1. Hastaların yaş gruplarına göre dağılımı $(\mathrm{p}=0.038)$

\begin{tabular}{|l|c|c|c|c|c|c|}
\hline Yaş Grupları & \multicolumn{2}{|c|}{ Sistitli Hastalar } & \multicolumn{2}{c|}{ Piyelonefritli Hastalar } & \multicolumn{2}{c|}{ Tüm Hastalar } \\
\hline & $\mathrm{n}$ & $\%$ & $\mathrm{n}$ & $\%$ & $\mathrm{n}$ & $\%$ \\
\hline 5 yaş ve altı & 4 & 18.2 & 18 & 81.8 & 22 & 31.4 \\
\hline 5 yaşın üzeri & 21 & 43.7 & 27 & 56.3 & 48 & 68.6 \\
\hline Toplam & 25 & 35.7 & 45 & 64.3 & 70 & 100.0 \\
\hline
\end{tabular}

Tablo-2: Sistit ve piyelonefritli hastaların klinik dağılımları

\begin{tabular}{|c|c|c|c|c|}
\hline \multirow[t]{2}{*}{ Klinik } & \multicolumn{2}{|c|}{$\begin{array}{c}\text { Sistitli } \\
\text { Hastalar }(n=25)\end{array}$} & \multicolumn{2}{|c|}{$\begin{array}{c}\text { Piyelonefritli } \\
\text { Hastalar }(n=45)\end{array}$} \\
\hline & \multicolumn{2}{|c|}{$\mathrm{n} \quad \%$} & \multicolumn{2}{|c|}{$\mathrm{n} \quad \%$} \\
\hline Ateş & 8 & 32.0 & 41 & 91.1 \\
\hline S1k sık idrar yapma & 17 & 68.0 & 18 & 40.0 \\
\hline Karın ağr1s1 & 10 & 40.0 & 23 & 51.1 \\
\hline İdrar yaparken yanma & 14 & 56.0 & 16 & 35.6 \\
\hline Kusma & 7 & 28.0 & 10 & 22.2 \\
\hline İdrar kaçırma & 13 & 52.0 & 3 & 6.7 \\
\hline Yan ağris1 & 7 & $28 ., 0$ & 7 & 15.6 \\
\hline Huzursuzluk & 5 & 20.0 & 4 & 8.9 \\
\hline Kanlı idrar yapma & - & - & 4 & 8.9 \\
\hline
\end{tabular}


Tablo 3. Hastaların kültürlerinde üreyen mikroorganizmaların dağılımı

\begin{tabular}{|c|c|c|c|}
\hline \multirow[t]{2}{*}{ Kültürde Üreyen Mikroorganizma } & Sistitli Hastalar & \multicolumn{2}{|c|}{ Piyelonefritli Hastalar } \\
\hline & $\mathrm{n} \quad \%$ & $\mathbf{n}$ & $\%$ \\
\hline Escherichia coli & 72.0 & 35 & 77.8 \\
\hline Proteus mirabilis & 16.0 & 6 & 13.3 \\
\hline Enterococcus faecium & 4.0 & 1 & 2.2 \\
\hline Staphylococcus aureus & 4.0 & 1 & 2.2 \\
\hline Citrobacter brachii & 4.0 & 1 & 2.2 \\
\hline Pseudomonas aeruginosa & - & 1 & 2.2 \\
\hline
\end{tabular}

Tablo 4. Değişken verilerin ortalama değerleri ve standart sapmaları ( $\mathrm{x} \pm \mathrm{ss})$

\begin{tabular}{|l|c|c|c|}
\hline Değişken Veriler & Sistitli Hastalar Hastalar & Piyelonefritli Hastalar & p Değeri \\
\hline & $(\mathrm{x} \pm \mathrm{ss})$ & $(\mathrm{x} \pm \mathrm{ss})$ & \\
\hline Beden $\left.1 \mathrm{~s} 1 \mathrm{~s} 1{ }^{\circ} \mathrm{C}\right)$ & $37.6 \pm 0.9$ & $38.8 \pm 0.5$ & 0.001 \\
\hline Lökosit $\left(/ \mathrm{mm}^{3}\right)$ & $9876 \pm 3894$ & $15442 \pm 3347$ & 0.001 \\
\hline C-reaktif protein $(\mathrm{mg} / \mathrm{dL})$ & $2.7 \pm 3.4$ & $7.7 \pm 6.0$ & 0.001 \\
\hline Sedimentasyon $(\mathrm{mm} / \mathrm{saat})$ & $18 \pm 17$ & $54 \pm 26$ & 0.001 \\
\hline
\end{tabular}

Tablo 5. Değişken verilerin akut piyelonefriti göstermede duyarlılık ve seçiciliği

\begin{tabular}{|l|c|c|c|c|c|}
\hline \multicolumn{1}{|c|}{ Değişken Veriler } & Kesme & Duyarlıl1k & Seçicilik & 'ROC & p Değeri \\
\hline & Değeri & $\mathbf{\%}$ & $\mathbf{\%}$ & Area' & \\
\hline Beden 1 s1s1 $\left({ }^{0} \mathrm{C}\right)$ & 38.4 & 90.0 & 85.0 & 0.91 & 0.001 \\
\hline Lökosit $\left(/ \mathrm{mrn}^{3}\right)$ & 12500 & 84.0 & 80.0 & 0.91 & 0.001 \\
\hline C-reaktif protein $(\mathrm{mg} / \mathrm{dL})$ & 2.9 & 82.0 & 80.0 & 0.83 & 0.001 \\
\hline Sedimentasyon $(\mathrm{mm} / \mathrm{saat})$ & 29 & 80.0 & 78.0 & 0.86 & 0.001 \\
\hline
\end{tabular}

Tablo-6: Hastalarda tedavinin başlama süresinin DMSA sintigrafide saptanan böbrek parankim zedelenmesi üzerine etkisi $(\mathrm{p}=0,001)$

\begin{tabular}{|c|c|c|c|c|c|c|}
\hline \multirow[t]{3}{*}{ Tedaviye başlama süresi } & \multicolumn{4}{|c|}{ Böbrek Parankiminde Zedelenme } & \multicolumn{2}{|c|}{ Toplam } \\
\hline & & $\operatorname{Var}(+)$ & Yok & & $\mathrm{n}$ & $\%$ \\
\hline & $\mathrm{n}$ & $\%$ & $\mathrm{n}$ & $\%$ & & \\
\hline 48 saat ve altında & 8 & 30.8 & 18 & 69.2 & 26 & 37.1 \\
\hline 48 saatin üzerinde & 37 & 84.1 & 7 & 15.9 & 44 & 62.9 \\
\hline Toplam & 45 & 64.3 & 25 & 35.7 & 70 & 100.0 \\
\hline
\end{tabular}

\section{TARTIŞMA}

Çocuklarda piyelonefrit, akut morbiditeye neden olabileceği gibi ileriki y1llarda hipertansiyon ve kronik böbrek yetmezliğine öncülük edebilecek böbrek parankim zedelenmesiyle de ilişkilidir. Yaş azaldıkça piyelonefritli olgu görülme oranının arttı̆̆ bilinmektedir. Böbrek parankiminde zedelenmenin 5 yaşın altında saptanması, daha sonraki yıllarda geri dönüşümsüz skar ve kronik piyelonefrit oluşum sılklığını $\operatorname{arttırır}^{1-3}$.

Çalışmamızda yer alan piyelonefritli olgularımızın sistitli olgulara oranına baktığımızda 5 yaşın üzerinde bu oranın 1,3/1 olduğu gözlenirken, 5 yaş ve altındaki oranın 4.5/1 olduğu saptandı. Erkeklerin \% 2 'sinin, kızların ise \% 8'inin çocukluk döneminde en az bir kez iYE geçirdiği bilinmektedir. Yenidoğan dönemi dışında yaşamın tüm dönemlerinde IYE, kızlarda erkeklere göre sık görülür. Kızlarda IYE'nun sık görülmesinin nedeni üretranın kısa oluşu ve dışkı bulaşması ile asendan enfeksiyonun kolaylıkla oluşmasıdır ${ }^{(7,8)}$. Bizim çalışmamızda da kız çocuklarında IYE görülme oranı erkeklerden 2 kat fazlaydi; ancak, kız ve erkek olgularımızın yaş gruplarına göre dağılımı istatistiksel olarak anlamlı değildi. Çocuklarda IYE'nun klinik bulgusu, enflamasyonun yoğunluğuna bağlı olduğu gibi enfeksiyonun düzeyi ve hastanın yaşıyla da ilişkilidir. Çocuklarda 2 yaşın altında ağrilı idrar yapma, sık sık idrara çıkma, pubis üzerinde ağrı, yan ya da bel ağrısı genellikle saptanamaz. Aileler bu yaş grubundaki çocukları ateş, ishal, kusma, kilo alamama ve kilo kaybı gibi özgün olmayan şikayetlerle getirir. Kokulu 
ya da kanlı idrar yapma şikayeti ile de getirilebilir. Beş yaşından sonra idrar yolu enfeksiyonu için daha özgün bulgular saptanır. İdrar kaçırma ve gece altını ıslatma, tuvalet eğitimi almış olan çocuklarda IYE'nun tek bulgusu olabileceği gibi, s1klıkla yalnızca ateş şikayeti ile getirilirr ${ }^{1,9}$. Çalışmamız kapsamında yer alan her 10 çocuktan 7'sinde ateş saptanarak, mevcut kaynaklarla uyumlu bulundu ${ }^{10,11}$. Olgularımızın kliniğe getirilme şikayetleri arasında ikinci sırayı, sık sık idrar yapma alırken, bunu sırasıyla karın ağrısı ve idrar yaparken yanma şikayeti izledi. Bu şikayetler olgularımızın yarısında vardı. Çalışma kapsamındaki her 10 olgudan 7'sinin 5 yaşın üzerinde olması nedeniyle, idrar yapma ile ilgili sorunlar ve ağrı şikayeti üst siralarda yer aldı.

Çocukluk çağında IYYE'nun en sık (\% 90) etkeni Escherichia coli'dir. Escherichia coli'den sonra Enterococcus faecium, Klebsiella pneumonia, Proteus mirabilis, Pseudomonas aeroginosa, Citrobacter brachii, Staphylococcus aureus ve Candida albicans'ın yer aldığ1 bilinmektedir ${ }^{12,13}$. Çalışma kapsamına alınan olgularımızın idrar kültüründe Escherichia coli'den sonra ikinci sırayı Proteus mirabilis almaktaydi. En az sayıda üreyen mikroorganizmanın Pseudomonas aeruginosa olduğu gözlendi. Hiçbir olgumuzda Klebsiella pneumonia ve Candida üremedi. Yapılan çalışmalarda, idrar kültüründe ikinci sıklıkla ürediği saptanan mikroorganizma Proteus mirabilis iken, bazı çalışmalarda ise Klebsiella pneumonia'nın 2 . sıklıkla ürediği bildirilmiștir ${ }^{14,15}$.

Akut piyelonefritli hastalarda enflamasyonun böbreğe yayılımı ile yaygın enflamasyonun yanıtı olan ateş, lökosit sayısında artış, CRP ve sedimentasyon yüksekliği gözlenirken, sistitte enflamasyonun alt idrar yoluna sinirlı olduğu bilinmektedir. Yine de bu enflamasyon göstergeleri piyelonefrit ve sistit ayrımında özgünlük göstermemektedir. Bazı yayınlarda, ateş varlığının piyelonefriti saptamada oldukça önemli bir ölçüt olduğu vurgulanırken, bazı çalışmalarda ise ateşin piyelonefrit tanısında anlamlılık göstermediği, hatta DMSA sintigrafi ile normal ve anormal böbrek parankim görüntülemeleri saptanan çocukların aynı beden 1sısına sahip olduğu bildirilmiştir ${ }^{16-19}$. Bizim çalışmamızda, olgularımızın beden 1sısı, lökosit sayısı, CRP ve sedimentasyon değerleri piyelonefritli olgularımızda anlamlı derecede yüksekti.

Akut piyelonefrit tanısı genellikle klinik, laboratuvar ve pozitif idrar kültürüyle konulmaktadır. Ancak, klinik ve laboratuvar bulgularının piyelonefrit tanısını koymada duyarlılık ve seçiciliği yüksek değildir. Buna karşıllk akut piyelonefrit tanısında DMSA sintigrafinin duyarlılığ $\%$ \%9, seçiciliği ise \% 91 olarak bildirilmiştir ${ }^{16,20,21}$. Biz de çalışmamızda klinik bulgulardan ateş ile laboratuvar tetkiklerinden lökosit sayısının, CRP ve sedimentasyon değerlerinin duyarlılık, seçicilik, kesme noktaları ve "ROC Area" değerlerini saptadık. Koltuk altından ölçülen beden ısısının kesme değerini $38,4^{\circ} \mathrm{C}$ aldığımızda, akut piyelonefriti belirlemede duyarlıllı̆̆ $\% 90$ ve seçiciliği ise \% 85 olarak belirlendi. Ateşin "ROC Area" değeri 0.91 olarak saptandi.

Lökosit yüksekliğinin IYE'nun düzeyini belirlemede, dolayısıyla da piyelonefrit tanısını desteklemede oldukça önemli bir tetkik olduğunu destekleyen yayınlar vardır22,23. Çalışmamızda, lökosit sayısının kesme değeri $12500 / \mathrm{mm}^{3}$ alındığında piyelonefrit tanısını koymada duyarlılı̆̆ın \% 84 ve seçiciliğin ise \% 80 olduğu saptandı. Lökosit için "ROC Area" değeri 0.91 bulundu. $\mathrm{Bu}$ sonucumuz literatürle desteklenmekteydi. Fernandez-Menendez ve ark. İspanya'da yaptıkları çalışmada lökosit için kesme değeri $15000 / \mathrm{mm}^{3}$ aldığında duyarlılığı \% $\quad 57$, seçiciliği \% 65 ve "ROC Area" değerini de 0.60 olarak bildirmiştir ${ }^{10}$. $\mathrm{Bu}$ çalışmada bildirilen duyarlılık ve "ROC Area" değeri bizim sonuçlarımızın oldukça altındaydı. İtalya'daki bir başka çalışmada, Biggi ve ark. lökosit için kesme değeri $14601 / \mathrm{mm}^{3}$ alarak, duyarlılığını \% 56 ve seçiciliğini $\% 58$ bildirmiştir ${ }^{16}$.

CRP, piyelonefriti saptamada kullanılan bir tetkiktir ${ }^{14,22}$. Çalışmamızda, CRP'nin kesme değeri $2,9 \mathrm{mg} / \mathrm{dL}$ alındığında duyarlılığı \% 82, seçiciliği \% 80 ve "ROC Area" değeri 0.83 olarak saptandi. İspanya'da Fernandez-Menendez ve ark. CRP'nin kesme değerini $3 \mathrm{mg} / \mathrm{dL}$ aldıklarında duyarlılığı \% 79, seçiciliği \% 55 ve "ROC Area" değerini 0,67 olarak bildirmiştir ${ }^{10}$. Çalışmamızda duyarlılık ve seçicilik daha yüksek bulunurken, "ROC Area" değeri daha anlamlıydı. Biggi ve ark. CRP'nin kesme değerini 88mg/dL alarak, duyarlılığı \% 64, seçiciliği ise \% 68 olarak bildirmiştir ${ }^{16}$. Bu sonuçlar, bizim bulduğumuz duyarlılık ve seçicilik değerlerinin oldukça altındadır.

Sedimentasyon, y1llardan beri IYE'nun düzeyini belirlemede kullanılan yardımcı bir tetkiktir ${ }^{14}$. Sedimentasyon için kesme noktasını $29 \mathrm{~mm} /$ saat aldığımızda, duyarlılığını \% 80, seçiciliğini \% 78 ve "ROC Area" değerini de 0,86 olarak saptadık. İspanya'da yapılan çalışmada sedimentasyonun kesme değeri $30 \mathrm{~mm} / \mathrm{saat}$ alınarak, duyarlılı̆g1 \% 69, 
seçiciliği \% 46, "ROC Area" değeri 0,58 olarak bildirilmiștir ${ }^{10}$. Bizim çalışmamızda saptanan duyarlılık, seçicilik ve 'ROC Area' değeri, bu çalışmada bildirilen değerlerin üzerinde bulundu. İtalya'da yapılan bir başka çalışmada ise, sedimentasyonun kesme değeri $68 \mathrm{~mm} /$ saat alınarak, duyarlılığ1 \% 48, seçiciliği \% 50 olarak bildirilmiştir ${ }^{16}$. Bizim sonuçlarımızın oldukça altında olduğu görülmektedir.

Çalışma kapsamındaki olgularımızda ateş, lökosit sayıs1, CRP ve sedimentasyon değerlerinin, DMSA sintigrafide saptanan parankim zedelenmesinin şiddetini göstermede istatistiksel olarak anlamlılik taşımadığını saptadık. Yurt dışında yapılan benzer bir çalışmada ise böbrek tutulumunun şiddetini göstermede yalnızca lökosit sayısında artış ve CRP yüksekliğinin istatistiksel olarak anlamlılık taşıdığı bildirilmiştir ${ }^{16}$. Bu konuyla ilgili daha kapsamlı çalışmalara gereksinim olduğu düşüncesindeyiz.

DMSA sintigrafi, akut piyelonefrit tanısinda kullanıldığ1 gibi enfeksiyonun akut döneminde oluşan böbrek parankim zedelenmesini saptamada ve zedelenmenin izlenmesinde de kullanılmaktadır. Böbrek parankim zedelenmesini göstermede, DMSA sintigrafiden başka teknikler de vardır; ancak, parankim zedelenmesini göstermede en duyarlı yöntem olarak DMSA sintigrafi kabul edilmektedir ${ }^{19,24}$.

Böbrekteki parankim zedelenmesini göstermede, alternatif yöntemlerden biri de $\mathrm{MAG}_{3}$ sintigrafidir. $\mathrm{MAG}_{3}$ sintigrafinin yüksek kalitede görüntüleme, düşük doz radyasyona maruz kalma, kısa sürede sonuç verme, diüretikle uygulanması ile radyoaktif maddenin böbrekten hızla atılımı gibi DMSA sintigrafiye pek çok üstünlüğü olmasina rağmen, duyarlılık ve seçiciliği konusunda yapılmış sınırlı sayıda çalışma vardır ${ }^{25-27}$. Sfakianakis yaptı̆̆1 çalışmada, parankim zedelenmesini göstermede $\mathrm{MAG}_{3}$ sintigrafinin DMSA sintigrafi ile aynı duyarlılığ1 gösterdiğini, ancak seçiciliğinin daha düşük olduğunu bildirmiştir ${ }^{20}$. Bir başka çalışmada Yaylalı ve arkadaşları MAG 3 sintigrafinin, DMSA sintigrafiden daha az lezyon saptaması nedeniyle (duyarlılık \%92, seçicilik \%78) renal parankim değerlendirilmesinde DMSA sintigrafinin yerini alamayacağı sonucuna varmıştır ${ }^{(28)}$. Otukesh ve arkadaşları, DMSA sintigrafi ile saptanan fokal defektin $\mathrm{MAG}_{3}$ sintigrafi ile dışlanamayacağını vurgulamışıtır ${ }^{29}$. Gordon ve arkadaşları renal parankimal defektlerin değerlendirilmesinde, $\mathrm{MAG}_{3}$ sintigrafinin hem duyarlılığını hem de seçiciliğini \%
88 olarak bildirmiştir ${ }^{30}$. Bir başka çalışmada, $\mathrm{MAG}_{3}$ sintigrafinin duyarlılığ1 ve seçiciliği sırasıyla \% 92.6 ve $\% 95.5$ bulunmuştur ${ }^{31}$. Bizim olgularımızda ise, böbrek parankim zedelenmesini göstermede $\mathrm{MAG}_{3}$ sintigrafinin duyarlılı̆̆ının, yayınlarda bildirilen oranın aksine oldukça düşük olduğu (\% 32,5), seçiciliğinin ise yüksek olduğu $(\% 98,1)$ saptand.

Çalışma kapsamında yer alan çocuklarımızın idrar kültürlerinde üreyen mikroorganizmanın piyelonefritli ve sistitli olgularımız arasında farklılık göstermediği gözlendi. Bir başka deyişle, DMSA sintigrafide böbrek parankim zedelenmesi saptanan ve saptanmayan olgularımızın idrar kültüründe üreyen mikroorganizmalar arasında farklilık saptanmadı. Tayland ve Brezilya'da yapılan bir çalışmada, bizim çalışmamıza benzer şekilde E.Coli ve E.Coli dışındaki mikroorganizmaların böbrek skar gelişiminde farklılık göstermediği bildirilmiştir ${ }^{32,33}$. İspanya'da ise bizim bulgumuzdan farklı olarak, DMSA sintigrafide parankim zedelenmesi saptanan olgularda E.Coli dişındaki mikroorganizmaların varlığının daha anlamlı olduğu bildirilmiştir ${ }^{10}$.

IYY'nda, böbrek parankiminde zedelenme saptanırken tedaviye başlama zamanı dikkate alınmalıdır. Yapılan çalışmalarda, IYE'nda tanının gecikmesinin böbrek parankiminde zedelenme ile sonuçlanacağı, tedaviye erken başlanmasının da parankim zedelenmesini önleyeceği vurgulanarak, bu sürenin 24 saati geçmesi durumunda parankim zedelenmesi için yüksek risk oluşturduğu rapor edilmiştir ${ }^{34-36}$. Yapılan bir başka çalışmada ise, şikayetin başlaması ile tedavinin başlaması arasında geçen sürenin 48 saati geçmesi durumunda, DMSA sintigrafide saptanan böbrek parankiminde zedelenme riskinin daha yüksek olduğu bildirilmiştir ${ }^{10}$. Bizim çalışmamızda da bulguların başlaması ile tedavinin başlaması arasında geçen sürenin 48 saati aşması durumunda, parankimde zedelenme oluşum riskinin arttığı, bu durumun istatistiksel olarak oldukça anlamlı olduğu saptanırken, yapılmış olan çalışmalarla desteklendiği dikkat çekmiştir.

Sonuç olarak, bulgu veren ilk IYE olan çocuklarda, böbrek parankiminde gelişebilecek zedelenmenin önlenmesinde erken tanı ve tedavinin önemi bir kez daha açıkça ortaya konulmuştur. $\mathrm{MAG}_{3}$ sintigrafinin akut piyelonefriti ve böbrek parankim zedelenmesini belirlemede DMSA sintigrafinin yerini alamayacağ1 ve bu konuda yapılacak kapsamlı çalışmalara gereksinim olduğu kanısına varıldı. 


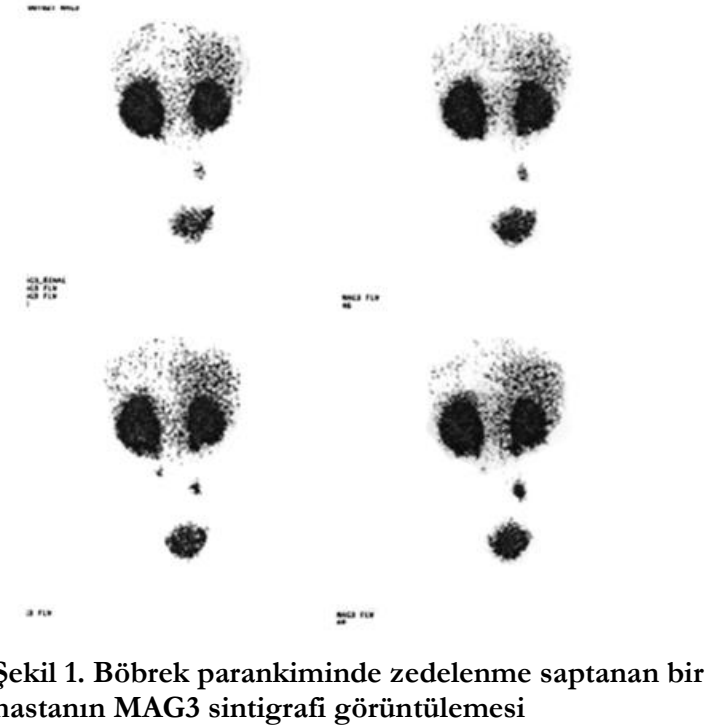

\section{KAYNAKLAR}

1. Ammenti A, Cataldi L, Chimenz R, Fanos V, La Manna A, Marra $G$ et al. Febrile urinary tract infections in young children: recommendations for the diagnosis, treatment and follow-up. Acta Pediatr. 2012;101:451-7.

2. Edefonti A, Tel F, Testa S, De Palma D. Febrile urinary tract infections: Clinical and laboratory diagnosis, imaging, and prognosis. Semin Nucl Med. 2014;44:123-8.

3. MacNeily AE. Pediatric urinary tract infections: current controversies. Can J Urol. 2001;8:18-23.

4. De Palma D, Manzoni G. Different imaging strategies in febrile urinary tract infection in childhood. What, when, why? Pediatr Radiol. 2013;43:436-43.

5. La Scola C, De Mutiis C, Hewitt IK, Puccio G, Toffolo A, Zucchetta P et al. Different guidelines for imaging after first UTI in febrile infants: Yield, cost, and radiation. Pediatrics. 2013;131:665-7.

6. Othman S, Al-Hawas A, Al-Maqtari R. Renal cortical imaging in children ${ }^{99 \mathrm{~m} T \mathrm{Tc}}$ MAG3 Versus ${ }^{99 \mathrm{~m} T \mathrm{C}}$ DMSA. Clin Nucl Med. 2012;37:351-5.

7. Sobel JD and Kaye D. Urinary tract infections. In Mandell, Douglas, and Bennett's Principles and Practice of Infectious Diseases, Mandell GL, Bennett JE, and Dolin R (editors). 5th ed. New York: Churchill Livingstone. 2000:774-800.

8. Hellerstein S. Urinary traet infections in children: pathophysiology, risk factors, and management. Infect Med. 2002;19:554-60.

9. American Academy of Pediatrics. Practice parameter: The diagnosis, treatment, and evaluation of the initial

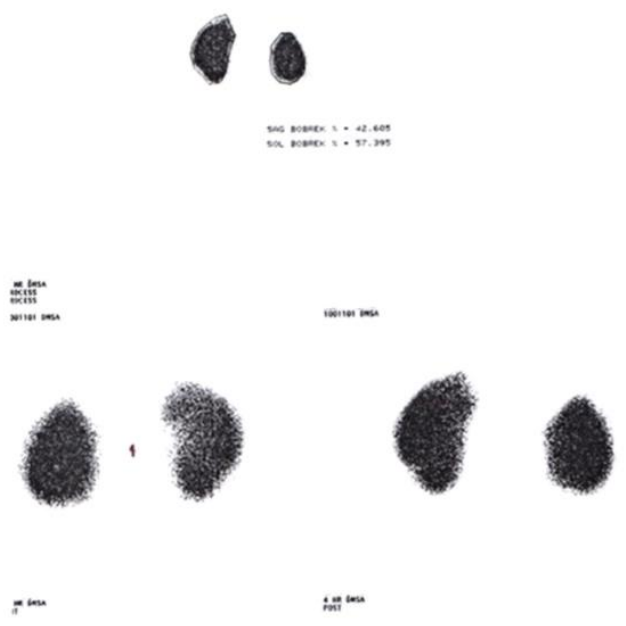

Şekil 2. Böbrek parankiminde zedelenme saptanan bir hastanın DMSA sintigrafi görüntülemesi

urinary tract infection in febrile infants and young children. Pediatrics. 1999;103:843-52.

10. Fernandez-Menendez JM, Malaga S, Matesanz JL, Solıs G, Alonso S, Perez-Mendez C. Risk factors in the development of early technetium-99m dimercaptosuccinic acid renal scintigraphy lesions during first urinary tract infection in children. Acta Pediatr. 2003;92:21-6.

11. Burbige KA, Retik AB, Colodny AH, Bauer SB, Lebowitz R. Urinary tract infections in boys. J Uro1. 1984;132:541-2.

12. Brandström P, Esbjörner E, Herthelius $\mathrm{M}$, Swerkersson S, Jodal U, Hansson S. The Swedish reflux trial in children: III. Urinary tract infection pattern. J Urol. 2010;184:286-91.

13. Hoberman A, Wald ER. Treatment of urinary tract infection. Pediatr Infect Dis J. 1999;18:1020-1.

14. Zaki M, Mutari GA, Badawi M, Ramadan D, AI deen Hanafy E. Vesicoureteric reflux in Kuwaiti children with first febrile urinary tract infection. Pediatr Nephrol. 2003;18:898-901.

15. Prais D, Straussberg R, Avitzur Y, Nussinovitch M, Harel L, Amir J. Bacterial susceptibility to oral antibiotics in community acquired urinary tract infection. Arch Dis Child. 2003;88:215-8.

16. Biggi A, Dardanelli L, Pomero G, Cussino P, Noello C, Sernia O. Acute renal cortical scintigraphy in children with a first urinary tract infection. Pediatr Nephrol. 2001;16:733-8.

17. Sobel JD and Kaye D. Urinary tract infections. In Mandell, Douglas, and Bennett's Principles and Practice of Infectious Diseases, Mandell GL, Bennett JE, and Dolin R (editors). 6th ed. Philadelphia: Elsevier; 2005.875-901.

18. Goldman M. Bistritzer T, Horne T. The etiology of 
renal scars in infants with pyelonephritis and vesieoureteral reflux. Pediatr Nephrol. 2000;14:385-8.

19. Garin EH, Olavarria F, Araya C, Broussain M, Barrera C, Young L. Diagnostic significance of clinical and laboratory findings to localize site of urinary infection. Pediatr Nephrol. 2007;22:1002-6.

20. Sfakianakis GN. Diuretic MAG3 scintigraphy (F0) in acute pyelonephritis: regional parenehymal dysfunction and comparisan with DMSA. J Nucl Med. 2000;41:1955-63.

21. Puseljie S, Arambasic J, Gardasanic J, Milas V, Puseljic I, Sipl M. The value of Tc-99m-DMSA renal scintigraphy in evaluation severity of parenchymal lesions in children with acute urinary tract infection. Acta Med Croatica. 2003;57:5-10.

22. Wald E. Urinary tract infections in infants and children: a comprehensive overview. Curr Opin Pediatr. 2004;16:85-8.

23. Hansson S, Martineli J, Stokland E, Jodal U. The natural history of bacteriuria in childhood. Infect Dis Clin North Am. 1997;11:499-512.

24. Sinha MD, Postlethwaite RJ. Urinary tract infections and the long-term risk of hypertension. Curr Pediatr. 2003;13:508-12.

25. De Bruyn R, Gordon i, MeHugh K. Imaging of the kidneys and urinary tract in children. In Diagnostic Radiology, Grainger RG, Allison DJ, Adam A, Dixon AK (editors). 4th ed. Edinburg: Churchill Livingstone. 2001:1717-64.

26. Hafez AT, McLorie G, Bagli D, Khoury A. Analysis of trends on serial ultrasound for high grade neonatal hydronephrosis. J Urol. 2002;168:1518-21.

27. Conway JJ. 'Well-Tempered' diuresis renography: Its historical development, physiological and technical pitfalls, and standardized technique protocol. Semin Nuc Med. 1992;22:74-84.

28. Yaylalı OT, Kıraç FS, Yüksel D. Performance of technetium-99m mercaptoacetyltriglycine scintigraphy in evaluation of renal parenchymal lesions: A comparative study with technetium- $99 \mathrm{~m}$ dimercaptosuccinic acid. Journal of Chinese Clinical Medicine. 2009;4:481-7.

29. Otukesh H, Fereshtehnejad SM, Jalali A. Early detection of renal scarring in children with suspected pyelonephritis: Comparison of diuretic MAG3 scintigraphy (F0) and DMSA scan. Med J Islam Repub Iran. 2007;21:17-24.

30. Gordon I, Anderson PJ, Lythgoe MF, Orton M. Can technetium-99m-mercaptoacetyltriglycine replace technetium-99mdimercaptosuccinic acid in the exclusion of a focal renal defect? J Nucl Med. 1992;33:2090-3.

31. Abdulrezzak U, Erdoğan Z, Kula M. Evaluation of renal parenchymal defects with $99 \mathrm{~m}$ technetium mercaptoacetyltriglycine scintigraphy using a modified grading and scoring system: comparison with $99 \mathrm{~m}$ technetium dimercaptosuccinic acid. Erciyes Medical Journal. 2013;35:18-23.

32. Tepmongkol S, Chotipanich C, Sirisalipoeh S, Chaiwatanarat $\mathrm{T}$, Vilaiehon AO, Wattana D. Relationship between vesicoureteral reflux and renal cortical scar development in Thai children: The significance of renal cortical scintigraphy and direct radionuclide cystography. J Med Assoc Thai. 2002;85:203-9.

33. Macedo CS, Riyuza MC, Bastos HD. Renal scars in children with primary vesicoureteral reflux. J Pediatr (Rio J). 2003;79:355-62.

34. Hiraoka M, Hashimoto G, Tsuchida S, Tsukahara H, Ohshima Y, Mayumi M. Early treatment of urinary infection prevents renal damage of cortical scintigraphy. Pediatr Nephrol. 2003;18:115-8.

35. Jakobsson B, Soderlundh S, Berg U. Diagnostic significance of $99 \mathrm{~m}-\mathrm{Tc}-$ dimercaptosuccinicacid (DMSA) scintigraphy in urinary tract infection. Arch Dis Child. 1992;67:1338-42.

36. Smellie JM, Poulton A, Prescod NP. Retrospective study of children with renal scarring associated with reflux and urinary infection. BMJ. 1994;308:1193-6. 